\title{
Genetic parameters and selection of micromineral-biofortified Andean bean lines with high technological quality
}

\section{Parâmetros genéticos e seleção de linhagens de feijão Andino com alta qualidade tecnológica e biofortificadas para microminerais}

\author{
Nerinéia Dalfollo Ribeiro ${ }^{\text {*; }}$ Henrique Caletti Mezzomo2; Greice Rosana Kläsener²
}

\section{Highlights}

Micromineral-biofortified Andean bean lines are unprecedented.

These traits showed high heritability $\left(h^{2} \geq 75.57 \%\right)$.

Lines DFA 39-18 and DFA 01-18 are iron-biofortified and have technological quality.

Lines DFA 03-18, DFA 27-18 and DFA 44-18 have high technological quality.

\begin{abstract}
The development of new micromineral-biofortified Andean bean cultivars with a grain pattern that meets consumers' requirements is unprecedented. This study proposes to obtain estimates of genetic parameters for technological-quality traits and micromineral concentration and to select superior Andean bean lines. The cross between cultivars Hooter and Cal 96 generated the recombinant inbred line population that was evaluated in the $F_{5: 6}$ and $F_{5: 7}$ generations. Technological quality was analyzed based on grain color determined in a colorimeter: $L^{*}$ (dark to light), $a^{*}$ (green to red) and b* (blue to yellow) values; and mass of 100 grains. Micromineral concentration (iron and zinc) was obtained by acid digestion. A significant genotype effect was found for all evaluated traits, except for zinc concentration in the $F_{5: 7}$ generation. $L^{*}$, $a^{*}$ and $b^{*}$ showed high heritability ( $\left.h^{2} \geq 90.85 \%\right)$ and qualitative inheritance. High heritability $\left(h^{2} \geq 75.57 \%\right)$ was also observed for mass of 100 grains and iron and zinc concentrations, which exhibited quantitative inheritance. Grains of the cranberry bean lines DFA 39-18 and DFA 01-18 are very light $\left(L^{*} \geq 52.18\right)$, with light red $\left(a^{*} \leq 9.49\right)$ and light yellow ( $b^{*} \leq 16.00$ ) shades; large (mass of 100 grains $>40 \mathrm{~g}$ ); and have high iron concentrations (Fe $\geq 95.00$ $\mathrm{mg} \mathrm{kg}^{-1}$ dry matter). Grains of the red mottled bean lines DFA 03-18, DFA 27-18 and DFA 44-18 exhibited high technological quality, i.e., they are dark (33.11 < $\left.L^{*}<37.28\right)$, light red $\left(16.24<a^{*}<18.72\right)$ and very light yellow (b* $\leq 9.45$ ) in shade, and large (mass of 100 grains $>40 \mathrm{~g}$ ). These lines will be selected by the breeding program.

Key words: Color pattern. Frequency distribution. Heritability. Scott-Knott. Selection index. Phaseolus vulgaris.

1 Prof $^{a}$ Dra ${ }^{a}$ Department of Plant Science, Federal University of Santa Maria, UFSM, Santa Maria, RS, Brazil. E-mail: nerineia@hotmail.com

2 Students of the Master's Course of the Pós-Graduate Program in Agronomy, UFSM, Santa Maria, RS, Brazil. E-mail: hc_mezzomo@hotmail.com; rosanaklasener@hotmail.com

* Author for correspondence
\end{abstract}

Received: Mar. 21, 2020 - Approved: Jan. 12, 2021 


\section{Resumo}

O desenvolvimento de novas cultivares de feijão Andino biofortificadas para microminerais e com padrão de grãos que atenda a demanda dos consumidores é inédito. Os objetivos desse trabalho foram obter estimativas de parâmetros genéticos para caracteres da qualidade tecnológica e concentração de microminerais e selecionar linhagens de feijão Andino superiores. O cruzamento entre as cultivares Hooter e Cal 96 gerou a população homozigota recombinante que foi avaliada nas gerações $F_{5: 6}$ e $F_{5: 7^{*}}$ A qualidade tecnológica foi analisada pela coloração dos grãos determinada em um colorímetro pelos valores de $L^{*}$ (escuro a claro), a* (verde a vermelho) e b* (azul a amarelo) e pela massa de 100 grãos. A concentração de microminerais (ferro e zinco) foi obtida por digestão ácida. Efeito significativo para genótipo foi verificado para todos os caracteres avaliados, exceto para a concentração de zinco na geração $F_{5: 7}$ Os valores de $L^{*}$, $a^{*}$ e $b^{*}$ apresentaram alta herdabilidade $\left(h^{2} \geq 90,85 \%\right)$ e herança qualitativa. Alta herdabilidade $\left(h^{2} \geq 75,57 \%\right)$ também foi observada para a massa de 100 grãos e a concentração de ferro e zinco, que mostraram herança quantitativa. Grãos das linhagens de feijão cranberry DFA 39-18 e DFA 01-18 são muito claros $\left(L^{*} \geq 52,18\right)$, com tonalidades vermelho claro $\left(a^{*} \leq 9,49\right)$ e amarelo claro $\left(b^{*} \leq 16,00\right)$; grandes (massa de 100 grãos $>40$ g); e têm alta concentração de ferro (Fe $\geq 95,00 \mathrm{mg} \mathrm{kg}^{-1}$ de matéria seca). Grãos das linhagens de feijão red mottled DFA 03-18, DFA 27-18 e DFA 44-18 mostram alta qualidade tecnológica, ou seja, são escuros $\left(33,11<L^{*}<37,28\right)$, com tonalidades vermelho claro $\left(16,24<a^{*}<18,72\right)$ e amarelo muito claro $\left(b^{*} \leq 9,45\right)$ e grandes (massa de 100 grãos $>40$ g). Essas linhagens serão selecionadas pelo programa de melhoramento. Palavras-chave: Padrão de cor. Distribuição de frequência. Herdabilidade. Skott-Knott. Índice de seleção. Phaseolus vulgaris.

\section{Introduction}

Common bean (Phaseolus vulgaris L.) is cultivated in several countries in tropical, subtropical and temperate regions of the world (Broughton et al., 2003). This crop is often the major source of protein, fibers and minerals in the human diet (Suárez-Martínez et al., 2016). Additionally, genetic variability has been reported in the iron and zinc concentrations in common bean genotypes (Blair, Astudillo, Grusak, Graham, \& Beebe, 2009; Cichy, Caldas, Snapp, \& Blair, 2009; N. D. Ribeiro, Steckling, Mezzomo, \& Somavilla, 2019b).

In Brazil, the most widely produced and consumed common bean grain types are carioca (beige seed coat with brown streaks) (70\%) and black (20\%) (Lemos, Mingotte, \& Farinelli, 2015), both belonging to the Mesoamerican gene pool. However, to increase the likelihood of a new common bean cultivar being accepted, breeding programs should observe grain color and size. In common bean, grain color can be assessed quantitatively by using a colorimeter, which measures the $L^{*}, a^{*}$ and $b^{*}$ values. In the case of carioca bean cultivars, grains must be very light to be accepted by consumers. Arns et al. (2018) recommended the following grain color pattern for carioca beans: greater lightness $\left(L^{*}\right.$ $\geq 55.00)$, light red $\left(a^{*} \leq 7.00\right)$ and light yellow $\left(b^{*}\right.$ $\leq 16.00$ ) shades. Black bean cultivars, in turn, should have very dark grains, i.e., $\mathrm{L}^{*} \leq 22.00$ ( $\mathrm{N}$. D. Ribeiro, Possebom, \& Storck, 2003) and a* and $b^{*}$ values near zero, which would indicate the lack of a secondary color (Possobom, Ribeiro, Zemolin, \& Arns, 2015; N. D. Ribeiro, Mezzomo, \& Santos, 2019a). Because these color patterns are associated with newly 
harvested and fast-cooking grains, they would be more appreciated by consumers. According to Carbonell, Chiorato, Gonçalves, Perina and Carvalho (2010), carioca and black bean grains must also be medium-sized (25 to $40 \mathrm{~g} 100$ grains $^{-1}$ ) to meet the market demand.

Cranberry (light cream seed coat with red streaks and patches) and red mottled (dark red seed coat with cream streaks) common bean grains are still grown on a small scale in Brazil. However, the production of these grain types can increase the income of family farms due to their high commercial value. Additionally, in highly technified production systems, the cultivation of these grain types would represent significant advances to the export of grains highly demanded in the international market. This scenario suggests a need to develop Andean bean cultivars with cranberry and red mottled grains that are adapted to the growing conditions in Brazil. Nevertheless, no studies have been found that propose grain color or size patterns for these types of grain while also meeting the preference of bean consumers.

Technological quality, grain color and size define the acceptance or rejection of a new common bean cultivar. If the common bean cultivar is biofortified for microminerals, it can be used as a food to solve nutrition problems affecting people of all ages and social classes, especially in Africa, Asia and Latin America. Breeding programs have put greater efforts into developing new iron- and zinc-biofortified Mesoamerican common bean lines (Blair et al., 2009; Jost et al., 2013; Martins et al., 2016; Maziero, Ribeiro, \& Facco, 2016; N. D. Ribeiro et al., 2019b). Results for iron- and zinc-biofortification in Andean beans have been obtained mostly in highly heterozygous generations (Mukamuhirwa, Tusiime, \& Mukankusi, 2015; Possobom et al.,
2015; Zemolin, Ribeiro, Casagrande, Silva, \& Arns, 2016).

The greater the knowledge about the phenotypic parameters of those traits, the more efficient the development of new micromineral-biofortified Andean bean cultivars of high technological quality. Estimates of the genetic parameters of heritability, coefficient of genetic variation and $b$ coefficient are useful to investigate genetic variability in the population and predict gains with the selection. Studies providing these estimates for the traits of color $\left(L^{*}, a^{*}\right.$ and $\left.b^{*}\right)$, mass of 100 grains, and iron and zinc concentrations in highly homozygous populations of Andean bean are unprecedented. Moreover, no studies exist that propose combined selection for high technological quality and micromineral biofortification in Andean bean. The release of new mineral-biofortified Andean bean cultivars with cranberry and red mottled grains with a grain pattern that meets consumers' preference represents an important innovation for breeding programs. Therefore, the present study was carried out to obtain estimates of genetic parameters for technological quality traits and micromineral concentration and to select biofortified Andean bean lines with cranberry and red mottled grains with high technological quality.

\section{Materials and Methods}

\section{Origin of Andean bean lines}

The $52 \mathrm{~F}_{5: 7}$ recombinant inbred lines (RIL) were developed from a cross made in 2012 between two common bean cultivars of the Andean gene pool: Hooter $\times$ Cal 96 . Hooter has a determinate (type I) growth 
habit, cranberry type grains, and was released in 2009 by the Seminis Seed Company for cultivation in the United States. Cal 96 has an indeterminate (type II) growth habit with short guides, red mottled type grains, and was released in 1998 by the National Agricultural Research Organization for cultivation in Uganda. These cultivars showed to be adapted to the growing conditions found in the southern region of Brazil (N. D. Ribeiro, Domingues, Gruhn, Zemolin, \& Rodrigues, 2014a) and to differ in iron and zinc concentrations (N. D. Ribeiro et al., 2014b).

The seeds obtained from this cross were advanced up to the $F_{5}$ generation by the Single-Seed Descent method. However, three seeds of each $F_{2}$ plant were sown and only one plant was kept after emergence. This procedure was repeated up to the $F_{5}$ generation so that all genetic variability observed in the $F_{2}$ generation would be preserved in a highly homozygous generation. The seeds of each $F_{5}$ plant were harvested individually and packed in paper bags. Only the plants that exhibited a sufficient number of seeds for the development of a field experiment were evaluated. Each $F_{5}$ plant generated was considered a RIL.

\section{Evaluation of Andean bean RILs}

Two experiments were conducted in the Common-Bean Breeding Program area at the Federal University of Santa Maria, in Santa Maria, Rio Grande do Sul (RS), Brazil (latitude $29^{\circ} 42^{\prime} \mathrm{S}$, longitude $53^{\circ} 43^{\prime} \mathrm{W}$, and 95 $\mathrm{m}$ above sea level). The climate of the region is a humid subtropical type with hot summers, without a clearly defined dry season. The soil in the experimental area is a typic alitic Argisol,
Hapludalf, which was prepared conventionally, with one plowing (by harrow) and one disking operation (to level the plot).

The $F_{5: 6}$ RILs were evaluated in an experiment established on November 13, 2017, which corresponds to the rainy-season crop period. The experiment was laid out in an augmented block design with three replicates. Treatments consisted of 61 Andean common bean genotypes, represented by $57 \mathrm{~F}_{5: 6}$ RILs, two parental cultivars (Hooter and Cal 96), and two control cultivars (Pérola and Iraí). The RILs were evaluated only once throughout the experiment (regular treatments) and the parental and control cultivars were included in the three replicates (common treatments). Thus, the means of the regular treatments were adjusted in relation to the blocks in analysis of variance.

The $\mathrm{F}_{5: 7}$ RILs were sown on February 27, 2018, during the dry-season crop period of 2018. The experiment was carried out in an $8 \times 8$ simple lattice design with two replicates, since a larger amount of seeds was available. Sixty-four Andean common bean genotypes were evaluated, consisting of $52 \mathrm{~F}_{5: 7}$ RILs, two parental cultivars (Hooter and Cal 96), and 10 control cultivars (Iraí, BRS MG Realce, Pérola, Carioca, BRS Estilo, Fepagro Garapiá, IAC Imperador, IPR Tangará, IPR Siriri and SCS Riqueza). In the second experiment, a higher number of control cultivars was included to keep the design balanced. Moreover, because only two Andean common bean cultivars are registered for cultivation in the RS state (Iraí and BRS MG Realce), it was also necessary to include control cultivars of Mesoamerican common bean with carioca beans that represent the most widely cultivated and consumed common bean type in Brazil. 
In both experiments, the experimental plot consisted of a 1-m row, spaced at 0.5 $\mathrm{m}$, with 15 seeds sown per linear meter. The management practices employed in the two experiments were uniform and similar and followed the technical recommendations for the common bean crop in RS state (Comissão Técnica Sul Brasileira de Feijão [CTSBF], 2012).

The plants were harvested and threshed manually at maturity (R9 stage) to prevent mechanical damage and grain contamination. The grains were then ovendried at $40^{\circ} \mathrm{C}$ until reaching $13 \%$ moisture. Subsequently, they were packed in paper bags, which were kept refrigerated (temperature: 5 ${ }^{\circ} \mathrm{C}$; air relative humidity: $75 \%$ ) throughout the evaluation period.

Determination of technological quality traits and micromineral concentration

Immediately after processing, the grains were evaluated for color and mass of 100 grains. Grain color was measured using a portable colorimeter (CR 410; Konica Minolta, Osaka, Japan), adopting the scale proposed by the International Commission on Illumination (CIE). This scale comprises three color axes: (1) $L^{*}$, which indicates luminosity, ranging from 0 (dark) to 100 (light); (2) $a^{*}$, which determines the degree of the colors green and red, with a negative $a^{*}$ value indicating a greener color and a positive $b^{*}$ value characterizing a redder color; and (3) $b^{*}$, which measures the degree of the colors blue and yellow, with a negative $\mathrm{b}^{*}$ value indicating a bluer color and a positive $b^{*}$ value denoting a yellower color. Mass of 100 grains was determined by weighing three random 100-grain samples. Color and mass of 100 grains were evaluated in triplicate in each experimental plot.
Micromineral concentration was analyzed in samples of $10 \mathrm{~g}$ of raw grains, which were ground in a micromill (Q298A21; Quimis, São Paulo, Brazil), without any previous treatment, until a fine (unsieved) flour was obtained. A 0.5-g aliquot of this flour was used for nitric-perchloric acid digestion, which was performed according to the methodology described by Miyazawa, Pavan, Muraoka, Carmo and Melo (2009). The final product of the digestion process was transferred to 50$\mathrm{mL}$ Falcon tubes, which were kept refrigerated (temperature: $5{ }^{\circ} \mathrm{C}$; air relative humidity: $75 \%)$, until the micromineral concentration was read. The iron and zinc concentrations were measured using an atomic absorption spectrophotometer (AAS Perkin Elmer AAnalyst 200; Waltham, United States) at the wavelengths of 248.30 and $213.0 \mathrm{~nm}$, respectively; results were expressed as milligrams per kilogram of dry matter $\left(\mathrm{mg} \mathrm{kg}^{-1}\right.$ DM).

\section{Statistical analyses}

The obtained data were subjected to individual analysis of variance. In the augmented block design experiment, the residual degree of freedom was obtained from the common treatments, since the regular treatments did not influence the estimate of the experimental error. In the second experiment, the efficiency of the lattice design in relation to the randomized block design was evaluated as described by Ramalho, Ferreira and Oliveira (2000).

Phenotypic parameters were obtained from the analysis of variance performed in each evaluated generation. The coefficient of experimental variation (CEV) and selective accuracy (SA) statistics were calculated 
as described by N. D. Ribeiro et al. (2017) and considered in the evaluation of the experimental precision of the evaluated traits. The following estimates of genetic parameters were obtained: heritability $\left(h^{2}\right)$, coefficient of genetic variation (CGV) and b coefficient. The $\mathrm{h}^{2}$ was estimated considering the mean of the treatments, using the formula described next:

$$
\mathrm{h}^{2}=\frac{\sigma^{2} \mathrm{G}}{\sigma^{2} \mathrm{P}}
$$

where $\sigma^{2} \mathrm{G}$ is the genetic variance and $\sigma^{2} \mathrm{P}$ is the phenotypic variance. The $F_{5: 6}$ and $F_{5: 7}$ RILs were highly homozygous; therefore, all genetic variation can be attributed to additive variance, i.e., the estimated $\mathrm{h}^{2}$ corresponded to narrowsense heritability. The CGV was obtained by the following expression:

$$
\mathrm{CGV}=100 \frac{\sqrt{G M S}}{\mathrm{~m}},
$$

where GMS corresponds to the genotype mean square and $m$ is the overall mean of the experiment. The $b$ coefficient was estimated as the ratio between CGV/CEV.

Frequency distribution for the means of the traits evaluated in the F5:6 and F5:7 generations was tested for normality by the Lilliefors test at the $5 \%$ probability level. Frequency distribution histograms were constructed for each evaluated trait in each generation, with the number of classes defined by the expression $\sqrt{n}$, where $\mathrm{n}=$ number of observations.

In order to select superior Andean common bean lines for technological quality traits and micromineral concentration, the data obtained in the $\mathrm{F}_{5: 7}$ generation were subjected to Scott-Knott test at the $5 \%$ probability level to evaluate the groups formed and to the selection index (multiplicative index). These analyses were performed only for the traits for which a significant genotype effect was observed in analysis of variance. For the multiplicative index (Subandi, Compton, \& Empig, 1973), a 10\% selection intensity was applied which resulted in the selection of six superior genotypes. Selection was performed with the aim of selecting common bean lines with cranberry grains (Hooter pattern), i.e., direct selection for $L^{*}$ value, mass of 100 grains, and iron concentration and inverse selection for the $a^{*}$ and $b^{*}$ values. Selection was also performed for common bean lines with red mottled grains (Cal 96 pattern), applying direct selection for mass of 100 grains and iron concentration and inverse selection for the $L^{*}$, $a^{*}$ and $b^{*}$ values. Frequency distribution graphs were also constructed using the Office Excel electronic spreadsheet and statistical analyses were carried out using Genes software (Cruz, 2016).

\section{Results and Discussion}

\section{Overall results}

A significant genotype effect ( $p$-value $<0.05$ ) was observed for all the evaluated traits, except zinc concentration in the $F_{5: 7}$ generation (Table 1). Therefore, there is genetic variability for grain color ( $\mathrm{L}^{*}, \mathrm{a}^{*}$ and $\mathrm{b}^{*}$ values), mass of 100 grains, and iron concentration in the two evaluated generations and for zinc concentration in the $F_{5: 6}$ generation. Similarly, common bean lines with a broad variation for $L^{*}$ (E. H. Ribeiro, Pereira, Coelho, \& Freitas, 2009; Erfatpour, Navabi, \& Pauls, 2018), a* and $b^{*}$ (Erfatpour et al., 2018), mass of 100 grains (E. H. Ribeiro et al., 2009; Blair et al., 2010a), and iron and zinc concentrations (Blair et al., 2009, 2010a; Cichy et al., 2009; Martins et al., 2016) were previously obtained from crosses 
between parents that are contrasting for those traits. These findings suggest the possibility of developing new micromineral-biofortified Andean bean cultivars of the cranberry and red mottled grain types with high technological quality.

The evaluated traits showed CEV values lower than $13.83 \%$ and SA values ranging from 0.52 to 0.99. Similar CEV and SA values have been described for $L^{*}, a^{*}$ and $b^{*}$ (Arns et al., 2018; N. D. Ribeiro et al., 2019a), mass of 100 grains (Arns et al., 2018), and iron and zinc concentrations (Martins et al., 2016; N. D. Ribeiro et al., 2019b) in experiments evaluating common bean lines. In the present study, the CEV $\leq 13.83 \%$ indicated high experimental precision in the evaluation of technological quality traits and micromineral concentration in experiments with RILs of common bean conducted in the augmented block and simple lattice designs. However, when the SA statistic was considered, very high experimental precision ( $S A \geq 0.90$ ) was obtained for all traits, except zinc concentration in the $\mathrm{F}_{5: 7}$ generation, which exhibited moderate experimental precision $(0.50<\mathrm{SA}<0.65)$ according to the classes established by de Resende and Duarte (2007). Zinc concentration in the $F_{5: 7}$ generation showed a $F$ test value for genotype lower than 2.00, and thus no significant difference was detected for genotype and no genetic parameter estimates were obtained for that trait. Therefore, SA showed to be more discriminatory than CEV to evaluate the experimental precision of technological quality traits and micromineral concentration in experiments with RILs of Andean bean conducted as incomplete designs.

In the $\mathrm{F}_{5: 7}$ generation, the efficiency of the simple lattice design ranged from 92.74 $\left(L^{*}\right)$ to $115.52 \%$ (zinc concentration), averaging $100.16 \%$ when the six evaluated traits were considered. These results warrant maintaining analysis of variance in the lattice design, as recommended by Ramalho et al. (2000). 
Table 1

Analysis of variance, estimates of mean and of phenotypic parameters for seed coat color ( $L^{*}, a^{*}$ and $b^{*}$

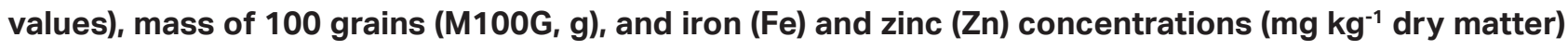
obtained in the Andean common bean lines in the $F_{5: 6}$ and $F_{5: 7}$ generations

\begin{tabular}{|c|c|c|c|c|c|c|c|}
\hline \multirow[t]{2}{*}{ Sources of variation } & \multirow[t]{2}{*}{$\mathrm{DF}^{1}$} & \multicolumn{6}{|c|}{ Mean square } \\
\hline & & $L^{*}$ & $a^{*}$ & $b^{*}$ & M100G & $\mathrm{Fe}$ & $\mathrm{Zn}$ \\
\hline & & \multicolumn{6}{|c|}{$\mathrm{F}_{5: 6}$ generation } \\
\hline Block & 2 & 55.62 & 7.87 & 11.81 & 92.67 & 558.12 & 58.32 \\
\hline Genotype (adjusted) & 60 & $107.98^{*}$ & $31.00^{*}$ & $13.72^{*}$ & $42.19^{*}$ & $170.16^{*}$ & $24.86^{*}$ \\
\hline Residue & 6 & 2.10 & 0.31 & 1.09 & 7.27 & 30.97 & 5.83 \\
\hline CEV $(\%)^{2}$ & & 2.84 & 4.89 & 9.05 & 5.94 & 6.74 & 6.69 \\
\hline Selective accuracy & & 0.99 & 0.99 & 0.96 & 0.91 & 0,90 & 0.87 \\
\hline General mean & & 51.26 & 11.01 & 11.60 & 44.58 & 81.10 & 35.61 \\
\hline No common mean - lines & & 51.10 & 11.46 & 11.54 & 45.39 & 82.60 & 36.08 \\
\hline Common mean - control & & 52.02 & 8.86 & 11.89 & 40.74 & 74.01 & 33.42 \\
\hline Phenotypic variance & & 103.96 & 29.19 & 11.93 & 29.78 & 165.66 & 27.95 \\
\hline Environmental variance & & 2.10 & 0.31 & 1.09 & 7.27 & 30.97 & 5.83 \\
\hline Genetic variance & & 101.86 & 28.88 & 10.84 & 22.50 & 134.69 & 22.12 \\
\hline Heritability (\%) & & 97.98 & 98.92 & 90.85 & 75.57 & 81.30 & 79.14 \\
\hline CGV $(\%)^{3}$ & & 19.75 & 46.88 & 28.54 & 10.45 & 14.05 & 13.04 \\
\hline \multirow[t]{2}{*}{ Coefficient $b^{4}$} & & 6.96 & 9.58 & 3.15 & 1.76 & 2.08 & 1.95 \\
\hline & & \multicolumn{6}{|c|}{$F_{5: 7}$ generation } \\
\hline Replicate & 1 & 0.87 & 1.41 & 0.28 & 42.90 & 73.55 & 30.22 \\
\hline Block/replicate (adjusted) & 14 & 3.06 & 1.05 & 2.96 & 32.78 & 36.21 & 35.07 \\
\hline Genotype (adjusted) & 63 & $197.63^{*}$ & $58.10^{*}$ & $35.85^{*}$ & $235.30^{*}$ & $303.22^{*}$ & $22.84^{\text {ns }}$ \\
\hline Residue & 49 & 4.55 & 1.37 & 1.90 & 35.27 & 51.02 & 16.73 \\
\hline $\operatorname{CEV}(\%)^{2}$ & & 4.11 & 11.28 & 10.19 & 11.51 & 9.75 & 13.83 \\
\hline Selective accuracy & & 0.99 & 0.98 & 0.97 & 0.92 & 0.91 & 0.52 \\
\hline Lattice efficiency (\%) & & 92.74 & 94.86 & 105.87 & 98.43 & 93.55 & 115.52 \\
\hline General mean & & 51.96 & 10.37 & 13.52 & 51.61 & 73.23 & 29.56 \\
\hline No common mean - lines & & 50.93 & 11.24 & 13.29 & 55.72 & 73.30 & 29.92 \\
\hline Common mean - control & & 56.45 & 6.62 & 14.57 & 33.79 & 74.27 & 28.58 \\
\hline Phenotypic variance & & 98.81 & 29.05 & 17.92 & 117.65 & 151.61 & - \\
\hline Environmental variance & & 2.27 & 0.68 & 0.95 & 17.64 & 25.51 & - \\
\hline Genetic variance & & 96.54 & 28.37 & 16.97 & 100.01 & 126.10 & - \\
\hline Heritability (\%) & & 97.70 & 97.64 & 94.70 & 85.01 & 83.17 & - \\
\hline CGV $(\%)^{3}$ & & 18.91 & 51.34 & 30.46 & 19.38 & 15.33 & - \\
\hline Coefficient $b^{4}$ & & 4.60 & 4.55 & 2.99 & 1.68 & 1.57 & - \\
\hline
\end{tabular}

${ }^{1}$ Degrees of freedom. ${ }^{2}$ Coefficient of environmental variation. ${ }^{3}$ Coefficient of genetic variation. ${ }^{4}$ Ratio of coefficient of genetic variation to coefficient of environmental variation. *Significant by the $\mathrm{F}$ test at 0.05 probability. 
Genetic parameters and inheritance of technological quality traits in Andean bean

High heritability $\left(h^{2} \geq 75.57 \%\right)$ was obtained for $L^{*}, a^{*}, b^{*}$, and mass of 100 grains (Table 1). The $L^{*}, a^{*}$ and $b^{*}$ values also showed high $\mathrm{h}^{2}$ when evaluated in a highly heterozygous generation of Andean and Mesoamerican bean populations (Possobom et al., 2015) and in a highly homozygous generation of a Mesoamerican bean population (N. D. Ribeiro et al., 2019a). Similarly, mass of 100 grains showed a high $h^{2}$ in different $F_{3}$ populations obtained from crosses between Andean and Mesoamerican parents (Mukamuhirwa et al., 2015). Traits with high $h^{2}$ can obtain greater gains with selection, since most part of the observed variation will be of genetic nature.

Greater contribution from genetic variation to the expression of $L^{*}, a^{*}, b^{*}$, and mass of 100 grains was confirmed by the high CGV values (10.45 to $51.34 \%$ ). No previous studies have been found that evaluate CGV for technological quality traits in Andean bean. However, high CGV values for $L^{*}$ and mass of 100 grains were observed when 185 RILs were evaluated in $\mathrm{F}_{7}$ generation of Mesoamerican bean with different grain types (E. H. Ribeiro et al., 2009). N. D. Ribeiro et al. (2019a) also observed high CGV values ( $\geq 42.89 \%$ ) for $L^{*}$, $a^{*}$ and $b^{*}$ in 100 RILs in $F_{5: 6}$ and $F_{5: 7}$ generations of Mesoamerican bean of the carioca and black grain types.

All technological quality traits exhibited b coefficients $\geq 1.68$, indicating great genetic variability for grain color ( $L^{*}, a^{*}$ and $b^{*}$ values) and mass of 100 grains among the Andean bean lines. Studies using the $b$ coefficient as an estimate of genetic variation of technological quality traits were found only evaluating Mesoamerican beans. E. H. Ribeiro et al. (2009) observed $b$ coefficients $>1.0$ for $L^{*}$ and mass of 100 grains in 185 RILs of common bean in the $F_{7}$ generation, whereas N. D. Ribeiro et al. (2019a) obtained such b coefficients for $L^{*}, a^{*}$ and $b^{*}$ in 100 RILs of common bean in the $F_{5: 6}$ and $F_{5: 7}$ generations. Traits with $b$ coefficients $>1.0$ represent a very favorable situation for selection, according to Vencovsky and Barriga (1992).

High magnitude estimates of the genetic parameters of $h^{2}, C G V$ and $b$ coefficient were obtained for the $L^{*}, a^{*}$ and $b^{*}$ values, and mass of 100 grains in Andean bean, indicating the existence of genetic variability among the evaluated lines. Thus, selection of Andean bean lines with cranberry and red mottled grains of high technological quality would be possible.

The $L^{*}, a^{*}$ and $b^{*}$ values did not show normal distribution in the $F_{5: 6}$ and $F_{5: 7}$ generations (Figures 1A, 1B, 1C, 1D, 1E and 1F). The frequency distribution histograms obtained in the two evaluated generations demonstrate the presence of few phenotypic classes for the $L^{*}, a^{*}$ and $b^{*}$, indicating that few genes act on the expression of color in Andean bean grains. Similar results were observed by Possobom et al. (2015) in $F_{2}$ progeny of Andean and Mesoamerican beans, revealing that $L^{*}, a^{*}$ and $b^{*}$ exhibited qualitative inheritance, regardless of gene pool. In a highly homozygous generation $\left(\mathrm{F}_{5: 6}\right.$ and $\left.\mathrm{F}_{5: 7}\right)$ of a population of Mesoamerican bean, N. D. Ribeiro et al. (2019a) described discontinuous variation, that is, the occurrence of few classes for $L^{*}, a^{*}$ and $b^{*}$.

For mass of 100 grains, normal distribution was detected by the Lilliefors test in the two evaluated generations (Figures 2A and $2 \mathrm{~B}$ ). Therefore, Andean bean lines with a mass of 100 grains lower and higher than those 
of their parents were obtained. The continuous variation indicates that mass of 100 grains in Andean bean is under polygenic control, i.e., quantitative inheritance.

In the present study, the $L^{*}, a^{*}$ and $b^{*}$ values showed qualitative inheritance and mass of 100 grains exhibited quantitative inheritance in Andean bean. Therefore, greater ease is expected in the selection of cranberry and red mottled lines with grain colors of greater acceptance by the market.

Genetic parameters and inheritance of micromineral concentration in Andean bean

The iron $\left(\mathrm{F}_{5: 6}\right.$ and $\mathrm{F}_{5: 7}$ generations) and zinc concentrations ( $F_{5: 6}$ generation) in Andean bean showed high heritability $\left(\mathrm{h}^{2}\right.$ $\geq 79.14 \%$ ) (Table 1), confirming the results observed by Mukamuhirwa et al. (2015) in a $\mathrm{F}_{3}$ generation obtained from a $6 \times 6$ diallel cross involving Andean and Mesoamerican parents. However, Zemolin et al. (2016) evaluated the $\mathrm{h}^{2}$ of iron and zinc concentrations in a $F_{2}$ generation developed from different crosses between Andean parents and reported values between 19.04 and $63.60 \%$, which characterize estimates of low to high magnitude according to the classification proposed by Soltani et al. (2016). Katuuramu et al. (2018), in turn, observed intermediate $\mathrm{h}^{2}$ values for the iron and zinc concentrations determined in cooked grains of 206 Andean bean genotypes evaluated in the United States. The observed differences can be explained by the method used to estimate heritability, evaluated generation, genetic diversity of the population and use of raw or cooked grains in the determination of the micromineral concentration in common bean genotypes. Heritability estimates are useful to evaluate the available genetic variability and predict gains with selection. High $\mathrm{h}^{2}$ values ( $\geq 60.00 \%$ ) are associated with greater genetic variability and with greater gains with selection, i.e., increased chances of success in the selection of superior genotypes for micromineral concentration. 

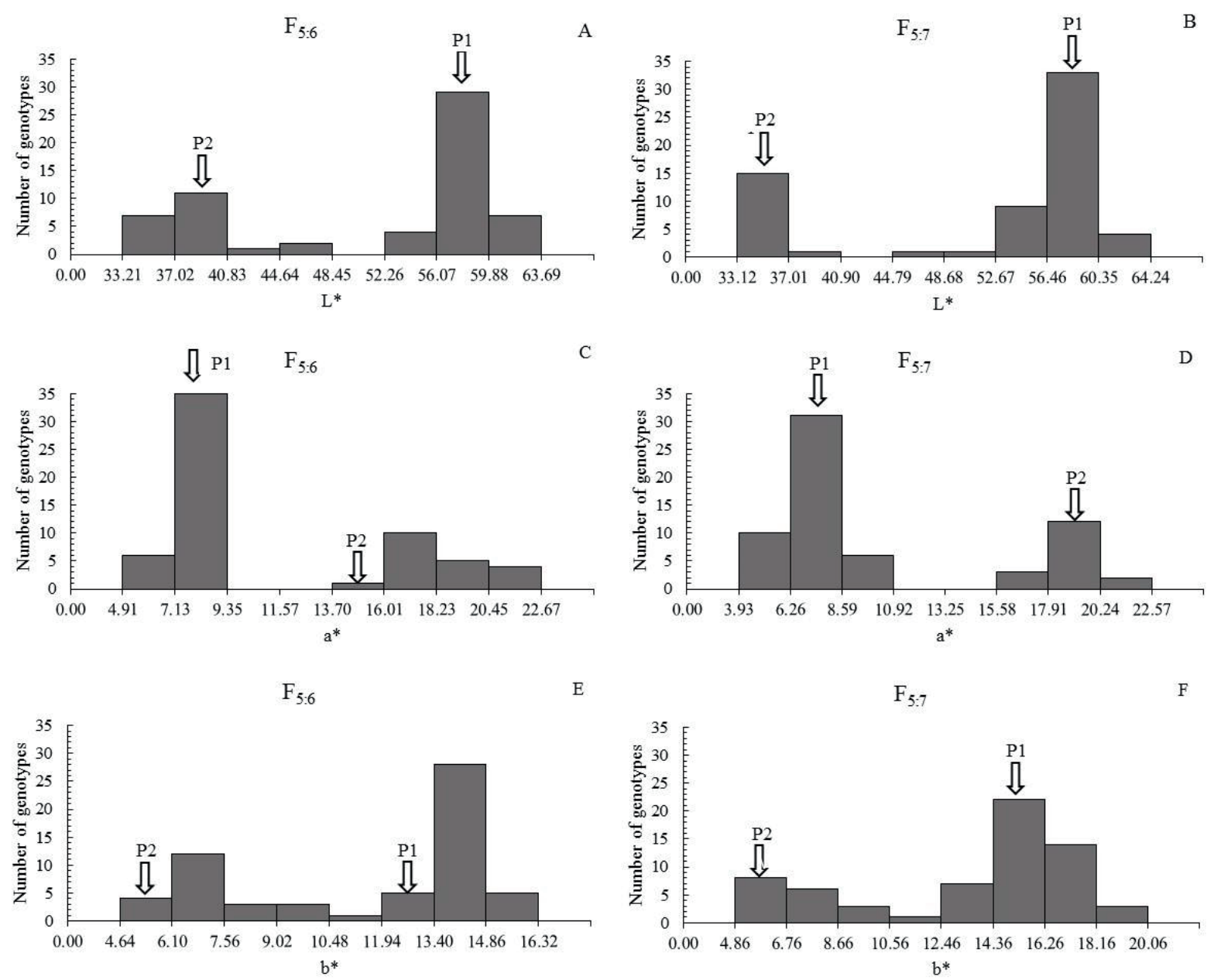

Figure 1. Frequency distribution histograms for seed coat color ( $L^{*}, a^{*}$, and $b^{*}$ values) obtained in the Andean common bean lines in the $F_{5: 6}$ and $F_{5: 7}$ generations. $P 1$ and $P 2$ are the parent cultivars: P1 (Hooter) and P2 (Cal 96).

Coefficients of genetic variation $\geq$ $13.04 \%$ and $b$ coefficients $\geq 1.57$ were detected for the iron concentration in the two evaluated generations and for the zinc concentration in the $F_{5: 6}$ generation, thus validating the hypothesis of greater contribution from genetic variation to the expression of those traits and favorable conditions for selection. The use of CGV and the $b$ coefficient as measures to estimate genetic variation in the iron and zinc concentrations in RILs is restricted to Mesoamerican bean. In this gene pool, more promising populations were identified for the selection of micromineral-biofortified common bean lines when the CGV and $b$ coefficient values were interpreted (Martins et al., 2016; Maziero et al., 2016; N. D. Ribeiro et al., 2019b). The populations that showed higher CGV and b coefficients $\geq 1.00$ exhibited greater genetic variability for the iron and zinc concentrations and were consequently the most promising for the selection of superior lines for the commonbean biofortification program. 

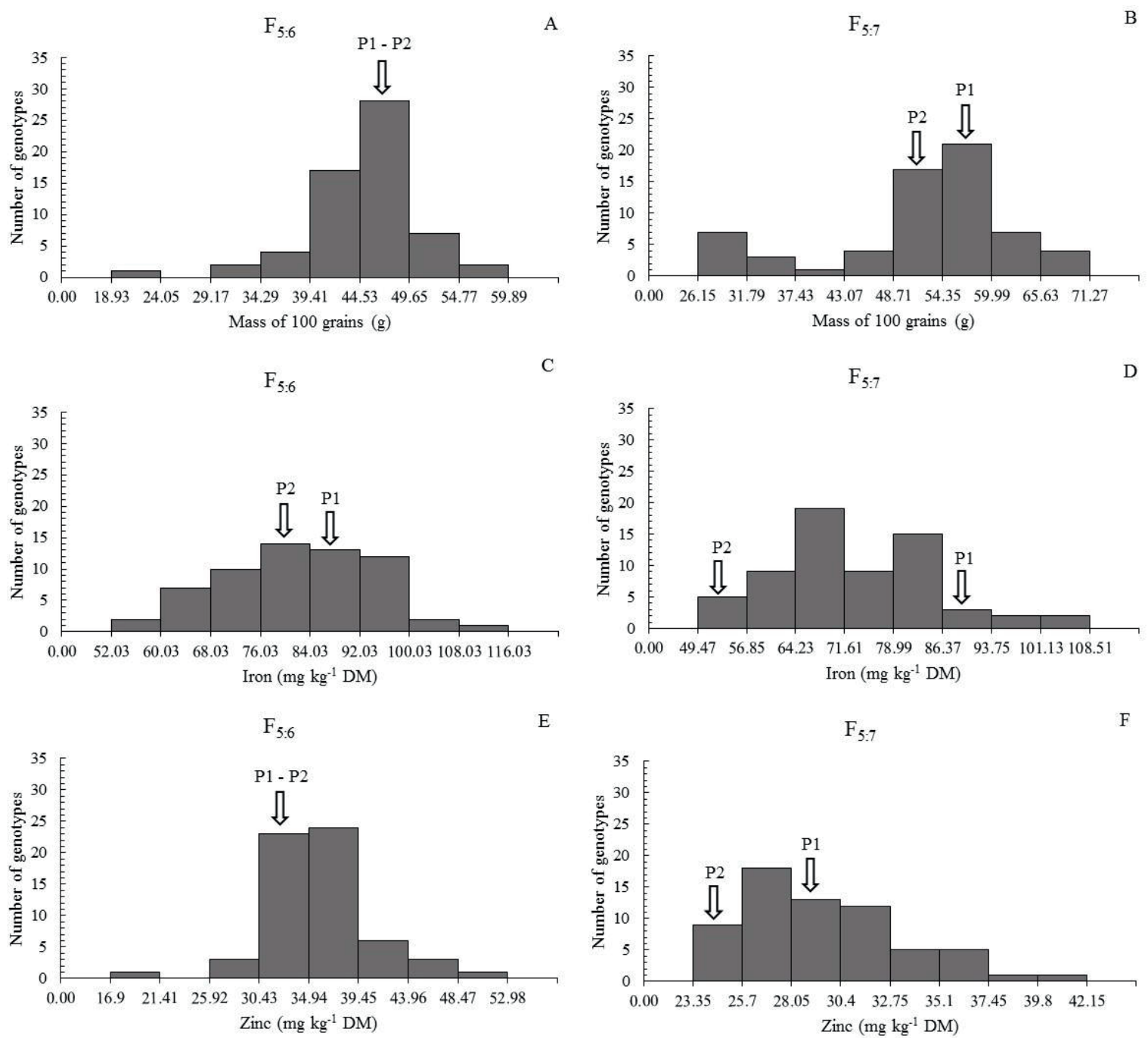

Figure 2. Frequency distribution histograms for mass of 100 grains and iron and zinc concentrations ( $\mathrm{mg} \mathrm{kg}^{-1}$ dry matter) obtained in the Andean common bean lines in the $F_{5: 6}$ and $F_{5: 7}$ generations. P1 and P2 are the parent cultivars: P1 (Hooter) and P2 (Cal 96).

According to the Lilliefors test, the iron and zinc concentrations exhibited normal distribution close to the mean in both generations (Figures 2C, 2D, 2E and 2F). The frequency distribution histograms revealed a continuous variation for the iron and zinc concentrations, which is characteristic of quantitative inheritance. Quantitative inheritance was previously described for the iron and zinc concentrations in RILs obtained from a cross between two Andean bean lines in the $F_{5: 7}$ generation (Cichy et al., 2009) and from one cross between two lines of different gene pools in the $\mathrm{F}_{7: 11}$ generation (Blair et al., 2009). Quantitative inheritance suggests that multiple loci are involved in homeostasis, accumulation and/or retention of those minerals in common bean (Katuuramu et al., 2018).

In the lines obtained from the cross between cultivars Hooter and Cal 96, the iron 
concentration ranged from 52.03 to 116.03 $\mathrm{mg} \mathrm{kg}^{-1} \mathrm{DM}$ in the $\mathrm{F}_{5: 6}$ generation (Figure $2 \mathrm{C}$ ) and from 49.47 to $108.51 \mathrm{mg} \mathrm{kg}^{-1}$ in the $F_{5: 7}$ generation (Figure $2 \mathrm{D}$ ). For zinc, the observed variation range was from 16.90 to $52.98 \mathrm{mg}$ $\mathrm{kg}^{-1} \mathrm{DM}$ and from 23.35 to $42.15 \mathrm{mg} \mathrm{kg}^{-1} \mathrm{DM}$ for the $F_{5: 6}$ and $F_{5: 7}$ generations, respectively (Figures 2E and 2F). Andean bean lines with iron and zinc concentrations higher than those present in their parents were obtained in the two evaluated generations, although transgressive segregation was not very evident. Likewise, Blair et al. (2010a) observed that the concentration of those microminerals did not exhibit a characteristic transgressive segregation in RILs in the $F_{10}$ generation obtained from a cross between two lines of Mesoamerican bean.

In the present study, the iron and zinc concentrations in Andean bean lines obtained from the Hooter $\times$ Cal 96 cross showed greater genetic variability, i.e., high $h^{2}$, higher CGV values and $b$ coefficient $\geq 1.00$. However, those traits exhibited quantitative inheritance, which may complicate the selection of micromineralbiofortified Andean bean lines with cranberry and red mottled grains.

\section{Selection of micromineral-biofortified Andean} bean lines with high technological quality

The Scott-Knott test resulted in the formation of three groups of genotypes for $L^{*}$, namely: (1) genotypes with greater lightness $L^{*}: 62.24$ to 52.18 , comprising all common bean genotypes with cranberry and carioca beans; (2) genotypes with intermediate lightness $L^{*}$ : 45.65, including only the line DFA 33-18 with red mottled beans; and (3) genotypes with lower lightness - $L^{*}: 37.28$ to 33.11 , grouping the other common bean genotypes with red mottled beans (Table 2). A similar variation range was previously observed for $L^{*}$ determined in common bean genotypes with cranberry (N. D. Ribeiro et al., 2014a), carioca (Arns et al., 2018) and kidney (red seed coat) beans (Parmar, Singh, Kaur, \& Thakur, 2017). 
Table 2

Means ${ }^{1}$ of seed coat color ( $L^{*}, a^{*}$ and b* values), mass of 100 grains (M100G, g), and iron (Fe) and zinc (Zn) concentrations ( $\mathrm{mg} \mathrm{kg}^{-1}$ dry matter) obtained in the Andean common bean lines in the $F_{5: 7}$ generation

\begin{tabular}{|c|c|c|c|c|c|c|c|}
\hline Genotype & Bean type & L & $a^{*}$ & $b^{*}$ & M100G & $\mathrm{Fe}$ & $\mathrm{Zn}$ \\
\hline DFA 32-18 & cranberry & $64.24 a^{*}$ & $5.97 e^{*}$ & $14.71 b^{*}$ & $60.62 a^{*}$ & $75.52 c^{*}$ & $33.23^{\text {ns }}$ \\
\hline IAC Imperador & carioca & $61.10 a$ & $4.41 \mathrm{e}$ & $14.95 b$ & $26.14 b$ & $72.07 \mathrm{c}$ & 25.71 \\
\hline DFA 16-18 & cranberry & $60.45 a$ & $8.11 d$ & $16.82 a$ & $61.96 a$ & $85.62 b$ & 29.35 \\
\hline IPR Siriri & carioca & $60.44 a$ & $5.08 e$ & $15.80 \mathrm{~b}$ & $26.28 b$ & $71.42 \mathrm{c}$ & 27.54 \\
\hline Carioca & carioca & $59.88 a$ & $4.15 \mathrm{e}$ & $14.61 \mathrm{~b}$ & $30.41 b$ & $62.22 \mathrm{c}$ & 25.65 \\
\hline DFA 26-18 & cranberry & $59.57 a$ & $7.10 d$ & $13.83 b$ & $58.90 a$ & $79.52 b$ & 25.88 \\
\hline DFA 19-18 & cranberry & $59.44 a$ & $8.78 d$ & $18.11 a$ & $55.77 a$ & $85.92 b$ & 28.03 \\
\hline Hooter & cranberry & $59.11 a$ & $6.80 d$ & $15.91 b$ & $57.83 a$ & $90.57 b$ & 28.72 \\
\hline DFA 01-18 & cranberry & $59.04 a$ & $7.30 d$ & $15.90 \mathrm{~b}$ & $58.18 a$ & $107.17 a$ & 35.34 \\
\hline DFA 18-18 & cranberry & $59.04 a$ & $8.37 d$ & $19.20 a$ & $55.08 a$ & $79.22 b$ & 28.90 \\
\hline DFA 48-18 & cranberry & $59.03 a$ & $8.54 d$ & $15.71 b$ & $49.76 a$ & 70.97c & 30.38 \\
\hline DFA 04-18 & cranberry & $58.67 a$ & $7.59 d$ & $15.01 \mathrm{~b}$ & $66.42 a$ & $76.57 b$ & 32.28 \\
\hline DFA 05-18 & cranberry & $58.55 a$ & $5.77 e$ & $11.82 b$ & $45.53 a$ & $84.32 b$ & 30.96 \\
\hline DFA 39-18 & cranberry & $58.51 a$ & $6.98 d$ & $15.42 b$ & $71.23 a$ & $108.52 a$ & 33.64 \\
\hline DFA 34-18 & cranberry & $58.48 a$ & $7.24 d$ & $15.37 b$ & $53.50 a$ & $64.37 c$ & 27.02 \\
\hline DFA 17-18 & cranberry & $58.25 a$ & $8.58 d$ & $16.55 a$ & $52.70 a$ & $71.52 \mathrm{c}$ & 31.42 \\
\hline DFA 31-18 & cranberry & $58.24 a$ & $7.01 d$ & $16.00 \mathrm{~b}$ & $60.69 a$ & $79.42 b$ & 29.63 \\
\hline DFA 20-18 & cranberry & $58.16 a$ & $6.72 d$ & $14.99 b$ & $51.06 a$ & $82.77 b$ & 28.68 \\
\hline DFA 36-18 & cranberry & $58.08 a$ & $8.10 d$ & $17.14 a$ & $60.11 a$ & $86.12 b$ & 28.36 \\
\hline DFA 37-18 & cranberry & $58.04 a$ & $8.36 d$ & $18.59 a$ & $60.73 a$ & $68.97 c$ & 32.71 \\
\hline BRS Estilo & carioca & $58.01 a$ & $4.55 e$ & $15.73 b$ & $33.84 b$ & $56.57 c$ & 25.64 \\
\hline DFA 40-18 & cranberry & $57.85 a$ & $7.70 d$ & $16.68 a$ & $53.63 a$ & $76.52 b$ & 27.25 \\
\hline DFA 43-18 & cranberry & $57.78 a$ & $7.22 d$ & $15.14 b$ & $47.18 a$ & $74.82 \mathrm{c}$ & 27.37 \\
\hline SCS 205 Riqueza & carioca & $57.76 a$ & $5.67 e$ & $17.26 a$ & $28.64 b$ & $74.12 \mathrm{c}$ & 27.36 \\
\hline DFA 47-18 & cranberry & $57.76 a$ & $8.23 d$ & $15.42 b$ & $56.44 a$ & $79.57 b$ & 30.07 \\
\hline Iraí & cranberry & $57.65 a$ & 7.97d & $13.62 b$ & $32.85 b$ & $74.57 c$ & 28.43 \\
\hline DFA 02-18 & cranberry & $57.63 a$ & $7.37 d$ & $16.73 a$ & $52.69 a$ & $65.02 \mathrm{c}$ & 32.29 \\
\hline IPR Tangará & carioca & $57.45 a$ & $3.93 e$ & $14.27 b$ & $27.87 b$ & $67.07 \mathrm{c}$ & 27.72 \\
\hline DFA 13-18 & cranberry & $57.44 a$ & $7.78 d$ & $12.65 b$ & $48.15 a$ & $65.82 \mathrm{c}$ & 34.54 \\
\hline DFA 51-18 & cranberry & $57.40 a$ & $8.21 d$ & $16.00 \mathrm{~b}$ & $59.16 a$ & $69.32 \mathrm{c}$ & 27.66 \\
\hline DFA 42-18 & cranberry & $57.30 a$ & $8.13 d$ & $13.48 \mathrm{~b}$ & $49.87 a$ & $72.92 \mathrm{c}$ & 27.69 \\
\hline Fepagro Garapiá & carioca & $57.34 a$ & $5.00 \mathrm{e}$ & $17.27 a$ & $29.11 b$ & $82.72 b$ & 38.63 \\
\hline DFA 21-18 & cranberry & $57.27 a$ & $7.04 d$ & $15.19 b$ & $57.00 a$ & $62.67 c$ & 32.54 \\
\hline DFA 22-18 & cranberry & $57.14 a$ & $9.49 d$ & $17.45 a$ & $58.54 a$ & $55.97 \mathrm{c}$ & 32.09 \\
\hline Pérola & carioca & $57.02 a$ & $4.55 e$ & $15.44 b$ & $29.18 b$ & $83.22 b$ & 28.23 \\
\hline DFA 45-18 & cranberry & $57.00 a$ & $7.32 d$ & $15.45 b$ & $54.70 a$ & $95.37 a$ & 32.34 \\
\hline
\end{tabular}


contuation...

\begin{tabular}{|c|c|c|c|c|c|c|c|}
\hline DFA 35-18 & cranberry & $56.78 a$ & $7.99 d$ & $16.30 a$ & $56.39 a$ & $60.12 c$ & 26.08 \\
\hline DFA 50-18 & cranberry & $56.18 a$ & $7.26 \mathrm{~d}$ & $13.10 b$ & $50.95 a$ & $79.67 b$ & 26.68 \\
\hline DFA 41-18 & cranberry & $55.99 a$ & $8.45 d$ & $17.36 a$ & $60.45 a$ & $79.80 b$ & 28.16 \\
\hline DFA 49-18 & cranberry & $55.82 a$ & $7.53 d$ & $15.33 b$ & $54.35 a$ & $67.02 \mathrm{c}$ & 28.61 \\
\hline DFA 29-18 & cranberry & $55.51 a$ & $8.49 d$ & $17.45 a$ & $58.46 a$ & $69.72 \mathrm{c}$ & 29.50 \\
\hline DFA 11-18 & cranberry & $55.36 a$ & $8.60 d$ & $17.53 a$ & $51.03 a$ & $87.47 b$ & 41.54 \\
\hline DFA 15-18 & cranberry & $55.36 a$ & $7.89 d$ & $17.62 a$ & $58.68 a$ & $79.42 b$ & 28.73 \\
\hline BRS MG Realce & cranberry & $55.30 a$ & $8.96 d$ & $13.42 b$ & $34.17 b$ & $91.37 b$ & 29.99 \\
\hline DFA 07-18 & cranberry & $55.01 a$ & $7.79 d$ & $20.46 a$ & $54.77 a$ & $65.42 \mathrm{c}$ & 31.44 \\
\hline DFA 09-18 & cranberry & $54.50 a$ & $9.30 d$ & $17.72 \mathrm{a}$ & $57.40 a$ & $72.87 c$ & 30.80 \\
\hline DFA 23-18 & cranberry & $52.18 a$ & $8.65 d$ & $14.96 b$ & $58.02 a$ & $64.32 c$ & 28.41 \\
\hline DFA 33-18 & red mottled & $45.65 b$ & $18.05 \mathrm{c}$ & $8.17 c$ & $56.52 a$ & $64.02 c$ & 28.47 \\
\hline DFA 14-18 & red mottled & $37.28 \mathrm{c}$ & $22.53 a$ & $9.45 c$ & $65.65 a$ & $66.92 \mathrm{c}$ & 33.92 \\
\hline DFA 06-18 & red mottled & $36.82 \mathrm{c}$ & $19.44 b$ & $6.92 c$ & $53.71 a$ & $69.22 \mathrm{c}$ & 33.14 \\
\hline DFA 10-18 & red mottled & $36.55 c$ & $16.99 c$ & $7.00 \mathrm{c}$ & $60.48 a$ & $52.12 \mathrm{c}$ & 34.81 \\
\hline DFA 52-18 & red mottled & $36.52 \mathrm{c}$ & $16.30 \mathrm{c}$ & $7.63 c$ & $51.66 a$ & $79.92 b$ & 28.41 \\
\hline CAL 96 & red mottled & $36.28 \mathrm{c}$ & $18.38 \mathrm{c}$ & $6.85 c$ & $49.10 a$ & $49.47 c$ & 25.39 \\
\hline DFA 28-18 & red mottled & $36.00 \mathrm{c}$ & $19.53 b$ & $6.65 c$ & $54.79 a$ & $60.47 c$ & 25.49 \\
\hline DFA 24-18 & red mottled & $35.93 c$ & $21.44 a$ & $8.96 c$ & $51.78 a$ & $61.42 \mathrm{c}$ & 25.01 \\
\hline DFA 38-18 & red mottled & $35.82 \mathrm{c}$ & $20.04 b$ & $5.75 c$ & $39.52 b$ & $60.92 c$ & 26.66 \\
\hline DFA 03-18 & red mottled & $35.46 c$ & $16.24 \mathrm{c}$ & $5.07 c$ & $69.30 a$ & $52.77 \mathrm{c}$ & 26.91 \\
\hline DFA 08-18 & red mottled & $35.11 \mathrm{c}$ & $19.42 b$ & $5.97 c$ & $53.76 a$ & $65.92 c$ & 25.55 \\
\hline DFA 25-18 & red mottled & $34.97 c$ & $18.72 \mathrm{c}$ & $6.80 c$ & $56.31 a$ & $65.77 \mathrm{c}$ & 27.04 \\
\hline DFA 46-18 & red mottled & $34.56 c$ & $18.50 \mathrm{c}$ & $7.17 c$ & $47.38 a$ & $60.67 c$ & 25.86 \\
\hline DFA 12-18 & red mottled & $34.24 c$ & $20.14 b$ & $9.38 c$ & $54.21 a$ & $99.87 a$ & 36.17 \\
\hline DFA 30-18 & red mottled & $33.73 c$ & $19.14 b$ & $7.01 \mathrm{c}$ & $56.45 a$ & $63.92 \mathrm{c}$ & 28.98 \\
\hline DFA 44-18 & red mottled & $33.23 c$ & $18.21 \mathrm{c}$ & $5.54 c$ & $51.61 a$ & $66.62 c$ & 27.74 \\
\hline DFA 27-18 & red mottled & $33.11 \mathrm{c}$ & $18.64 c$ & $5.77 c$ & $54.18 a$ & $70.77 c$ & 28.23 \\
\hline Mean & & 51.96 & 10.37 & 13.52 & 51.61 & 73.23 & 29.56 \\
\hline CV(\%) & & 4.10 & 11.28 & 10.19 & 11.51 & 9.75 & 13.84 \\
\hline
\end{tabular}

${ }^{1}$ Means followed by same letter in a column constitute a homogeneous group according to the Scott-Knott test at 0.05 probability. ns = non-significant.

Cranberry and carioca bean genotypes must have very light grains ( $L^{*}$ value) to be accepted by consumers, which associate greater lightness with newly harvested and fast-cooking grains. For carioca beans, N. D. Ribeiro, Storck, \& Poersch (2008) proposed L* $\geq 55.00$ as a standard for grain lightness. For cranberry beans, no proposal of a $L^{*}$ standard that meets the consumer preference was found. In the present study, the cranberry bean lines and the three control cultivars of this type of grain (Hooter, Iraí and BRS MG Realce) did not 
differ for the $L^{*}$ value. In this way, $L^{*} \geq 52.18$ can be recommended as a standard to be adopted in the selection of cranberry bean lines, as this value corresponds to the lightness of the grains of cultivars Hooter, Iraí and BRS MG Realce, which are already sold in the market.

Red mottled bean genotypes showed darker grains $\left(<L^{*}\right)$ when compared to the carioca and cranberry bean genotypes. However, there is not a standard $L^{*}$ value reference used in the selection of red mottled bean lines better accepted by consumers. In this study, the $L^{*}$ value of cultivar Cal 96 , the only red mottled bean cultivar evaluated, did not differ from those of the other lines with that grain type, except line DFA 33-18 $\left(L^{*}=45.65\right)$. Thus, it can be stated that red mottled bean lines with $L^{*}$ values from 33.11 to 37.28 have great chances of meeting the demands of common bean consumers, since their grain lightness is similar to that of cultivar Cal 96 , which is widely present in the human diet. Therefore, a $L^{*}$ value from 33.11 to 37.28 is proposed for the selection of red mottled bean lines.

However, grain color in common bean cannot be evaluated exclusively based on the $L^{*}$ value, since it did not differ between the cranberry and carioca bean genotypes, which confirms the results observed by Soares, Caliari, Bassinello, Fernandes and Becker (2012). Thus, it is important to also analyze the $a^{*}$ and $b^{*}$ values. When the common bean genotypes were evaluated for $a^{*}$, five groups were formed, whereas when $b^{*}$ was measured, the common bean genotypes were clustered in three groups. Therefore, $a^{*}$ was the most discriminatory grain color parameter in the differentiation between the cranberry, carioca and red mottled bean genotypes. Erfatpour et al. (2018) also found that $a^{*}$ was the most efficient parameter to be used in the differentiation of grain color between the cranberry and pinto bean genotypes.

For carioca beans, Arns et al. (2018) recommended that, in addition to greater lightness $\left(L^{*} \geq 55.00\right)$, grains should exhibit light red $\left(a^{*} \leq 7.00\right)$ and light yellow $\left(b^{*} \leq 16.00\right)$ shades. All evaluated carioca bean cultivars met this standard, except cultivars SCS 205 Riqueza and Fepagro Garapiá, which showed $b^{*} \geq 17.26$. For cranberry beans, the lines which showed the lightest red $\left(a^{*} \leq 9.49\right)$ and yellow $\left(b^{*} \leq 16.00\right)$ shades did not differ from the control cultivars with this type of grain, namely, Hooter, Iraí and BRS MG Realce. Therefore, when aiming at the selection of cranberry bean lines with lighter grains, the following standards are recommended: $L^{*} \geq$ 52.18, $a^{*} \leq 9.49$ and $b^{*} \leq 16.00$. However, red mottled beans are darker, as represented by lower $L^{*}$ and $b^{*}$ values and higher $a^{*}$ value. The red mottled bean lines which did not differ from the control cultivar Cal 96 exhibited $33.11<L^{*}$ $<37.28,16.24<a^{*}<18.72$ and $b^{*} \leq 9.45$, which are the recommended grain color standards in the selection of superior lines.

The common bean genotypes were clustered in two groups for mass of 100 grains: (1) lower mass of 100 grains ( $\leq 39.52 \mathrm{~g}$ ) included all carioca bean cultivars, the cranberry bean cultivars Iraí and BRS MG Realce and the red mottled bean line DFA 38-18; and (2) higher mass of 100 grains ( $\geq 45.53 \mathrm{~g}$ ) comprised all other evaluated genotypes of cranberry and red mottled beans. Therefore, the Scott-Knott test divided the common bean genotypes by

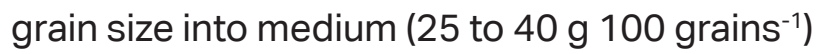

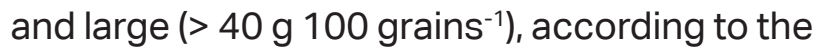
classes represented by Blair, González, Kimani and Butare (2010b). Because all evaluated carioca bean cultivars showed medium-sized grains, they meet the demands of consumers 
of this type of grain, as stated by Carbonell et al. (2010). However, there is a higher market demand for cranberry and red mottled bean cultivars with large grains, since consumers relate a larger grain size to increased yield after cooking. All cranberry and red mottled bean genotypes have large grains, except cultivars Iraí and BRS MG Realce and the line DFA 38-18.

Three cranberry bean lines (DFA $01-$ 18, DFA 39-18 and DFA 45-18) and one red mottled bean line (DFA 12-18) showed high iron concentration, which were previously defined by N. D. Ribeiro, Domingues, Zemolin and Possobom (2013) as values above 95.00 $\mathrm{mg} \mathrm{kg}^{-1} \mathrm{DM}$. Including iron-biofortified bean cultivars in the human diet is important for the prevention of clinical manifestations related to iron deficiency. Camaschella (2015) described the main recurring symptoms of iron deficiency in the human organism as being anemia, weakness, fatigue, difficulty concentrating and low productivity at work.

Although the genotype effect was not significant for the zinc concentration in the $F_{5: 7}$ generation (Table 1), 13 cranberry bean lines and four red mottled bean lines had a zinc concentration $\geq 31.00 \mathrm{mg} \mathrm{kg}^{-1} \mathrm{DM}$ (Table 2). This is a reference value for zinc biofortification programs, as it characterizes a high zinc concentration in common bean, according to Tryphone and Nchimbi-Msolla (2010). Clinical manifestations of zinc deficiency in the human organism are delayed growth, immune dysfunction and cognitive impairment (Prasad, 2014). Thus, including zinc-biofortified bean cultivars in the human diet may provide health benefits.

Genetic gains favorable to the objectives of selection of cranberry bean lines (Hooter pattern) were obtained for the traits of
$L^{*}(14.81 \%), a^{*}(-34.98 \%)$, mass of 100 grains (11.71\%), and iron concentration (20.10\%) (Table 3). Nonetheless, a positive gain was obtained for $b^{*}(7.51 \%)$, which is undesirable for this grain type.

The multiplicative index allowed the selection of the six superior cranberry bean genotypes for all evaluated traits, as follows: DFA 39-18, DFA 32-18, DFA 05-18, DFA 01-18, Hooter, and DFA 26-18. All selected genotypes exhibited a high $L^{*}(\geq 52.18)$, which characterizes very light grains; low $a^{*}(\leq 9.49)$, indicating a light red shade; low $b^{*}(\leq 16.00)$, characterizing a light yellow shade; and large grains (mass of 100 grains $>40 \mathrm{~g}$ ), i.e., they possess high technological quality. However, only the lines DFA 39-18 and DFA 01-18 were biofortified for iron. The multiplicative index was successfully applied in the simultaneous selection of mineral-biofortified Mesoamerican bean lines of high agronomic performance (Jost et al., 2013; Maziero, Ribeiro, \& Storck, 2015). Nevertheless, the use of the multiplicative index in the selection of iron-biofortified Andean bean lines with high technological quality is unprecedented in common bean.

When the multiplicative index was applied for the selection of red mottled bean lines (Cal 96 pattern), genetic gain estimates favorable to selection were observed for the traits of $L^{*}(-10.61 \%), b^{*}(-25.24 \%)$, mass of 100 grains $(11.09 \%)$ and iron concentration (9.61\%) (Table 3). However, only three of the selected lines showed red mottled beans: DFA 03-18, DFA 27-18 and DFA 44-18. This may be explained by the lower number of red mottled bean lines evaluated. 
Table 3

Means of the original population $\left(X_{0}\right)$, mean of the selected population $(X s)$, heritability $\left(h^{2}\right)$, genetic gain (GG), and percentage of genetic gain (GG, \%) with simultaneous selection by the multiplicative index for the six Andean common bean genotypes (10\% of the total lines evaluated) with cranberry beans (Hooter pattern) and red mottled beans (Cal 96 pattern) for seed coat color ( $L^{*}$, $a^{*}$ and $b^{*}$ values), mass of 100 grains $(M 100 \mathrm{G}, \mathrm{g})$, and iron concentration (Fe, $\mathrm{mg} \mathrm{kg}^{-1}$ dry matter) in the $F_{5: 7}$ generation

\begin{tabular}{|c|c|c|c|c|c|c|}
\hline Trait & $\mathrm{X}_{0}$ & $X_{s}$ & $h^{2}(\%)$ & GG & GG (\%) & \\
\hline \multicolumn{7}{|c|}{ Phenotypic parameters for cranberry beans } \\
\hline$L^{*}$ & 51.96 & 59.84 & 97.70 & 7.69 & 14.81 & \\
\hline$a^{*}$ & 10.37 & 6.66 & 97.64 & -3.63 & -34.98 & \\
\hline$b^{*}$ & 13.52 & 14.60 & 94.70 & 1.02 & 7.51 & \\
\hline M100G & 51.61 & 58.72 & 85.01 & 6.04 & 11.71 & \\
\hline $\mathrm{Fe}$ & 73.23 & 90.94 & 83.17 & 14.72 & 20.10 & \\
\hline Total gain & & & & 25.85 & 19.15 & \\
\hline \multirow[t]{2}{*}{ Trait } & \multicolumn{6}{|c|}{ Selected genotypes of cranberry beans } \\
\hline & DFA 39-18 & DFA 32-18 & DFA 05-18 & DFA 01-18 & Hooter & DFA 26-18 \\
\hline$L^{*}$ & 58.51 & 64.24 & 58.56 & 59.04 & 59.12 & 59.57 \\
\hline$a^{*}$ & 6.99 & 5.98 & 5.78 & 7.31 & 6.80 & 7.11 \\
\hline$b^{*}$ & 15.42 & 14.71 & 11.82 & 15.90 & 15.91 & 13.83 \\
\hline M100G & 71.24 & 60.63 & 45.53 & 58.19 & 57.84 & 58.91 \\
\hline $\mathrm{Fe}$ & 108.52 & 75.52 & 84.32 & 107.17 & 90.57 & 79.52 \\
\hline Trait & $\mathrm{X}_{0}$ & $X_{s}$ & $h^{2} \%$ & GG & GG\% & \\
\hline \multicolumn{7}{|c|}{ Phenotypic parameters for red mottled beans } \\
\hline$L^{*}$ & 51.96 & 46.32 & 97.70 & -5.51 & -10.61 & \\
\hline$a^{*}$ & 10.37 & 12.19 & 97.64 & 1.78 & 17.12 & \\
\hline$b^{*}$ & 13.52 & 9.92 & 94.70 & -3.41 & -25.24 & \\
\hline M100G & 51.61 & 58.34 & 85.01 & 5.72 & 11.09 & \\
\hline $\mathrm{Fe}$ & 73.23 & 81.69 & 83.17 & 7.04 & 9.61 & \\
\hline Total gain & & & & 5.61 & 1.97 & \\
\hline Trait & \multicolumn{6}{|c|}{ Selected genotypes of red mottled beans } \\
\hline & DFA 33-18 & DFA 39-18 & DFA $27-18$ & DFA 44-18 & DFA 05-18 & DFA 01-18 \\
\hline$L^{*}$ & 35.47 & 58.51 & 33.11 & 33.23 & 58.56 & 59.04 \\
\hline$a^{*}$ & 16.24 & 6.99 & 18.64 & 18.21 & 5.78 & 7.31 \\
\hline$b^{*}$ & 5.07 & 15.42 & 5.77 & 5.54 & 11.82 & 15.90 \\
\hline M100G & 69.31 & 71.24 & 54.18 & 51.62 & 45.53 & 58.19 \\
\hline $\mathrm{Fe}$ & 52.77 & 108.52 & 70.77 & 66.62 & 84.32 & 107.17 \\
\hline
\end{tabular}


The superior red mottled bean lines DFA 03-18, DFA 27-18 and DFA 44-18 stood out for high technological quality, with low $L^{*}$ (33.11 $<L^{*}<37.28$ ), characterizing dark grains; low $a^{*}\left(16.24<a^{*}<18.72\right)$, indicating a light red shade; low $b^{*}(\leq 9.45)$, denoting a very light yellow shade; and large grains (mass of 100 grains $>40 \mathrm{~g}$ ). However, none of those lines were biofortified for iron.

\section{Conclusion}

Grain color ( $L^{*}, a^{*}$ and $b^{*}$ values), mass of 100 grains and iron and zinc concentrations show high heritability ( $\mathrm{h}^{2} \geq 75.57 \%$ ) in the recombinant inbred line population of Andean bean, and qualitative inheritance is only observed for grain color.

Grains of the cranberry bean lines DFA 39-18 and DFA 01-18 are very light $\left(L^{*} \geq 52.18\right)$, with light red $\left(a^{*} \leq 9.49\right)$ and light yellow $\left(b^{*} \leq\right.$ 16.00) shades; large (mass of 100 grains $>40$ $\mathrm{g}$ ) and have high iron concentration ( $\mathrm{Fe} \geq 95.00$ $\mathrm{mg} \mathrm{kg}^{-1}$ dry matter). The selection of these lines for use in human nutrition and in breeding programs is therefore recommended.

Grains of the red mottled bean lines DFA 03-18, DFA 27-18 and DFA 44-18 have high technological quality: they are dark (33.11 $\left.<\mathrm{L}^{*}<37.28\right)$, with light red $\left(16.24<\mathrm{a}^{*}<18.72\right)$ and very light yellow $\left(b^{*} \leq 9.45\right)$ shades, and large (mass of 100 grains $>40 \mathrm{~g}$ ). Therefore, they will be selected by the breeding program.

\section{Acknowledgements}

To the National Council for Scientific and Technological Development (CNPq) for financial support and scholarships. To the
Coordination for the Improvement of Higher Education Personnel (CAPES) for the grants awarded.

\section{References}

Arns, F. D., Ribeiro, N. D., Mezzomo, H. C., Steckling, S. de M., Kläsener, G. R., \& Casagrande, C. R. (2018). Combined selection in carioca beans for grain size, slow darkening and fast-cooking after storage times. Euphytica, 214, 1-12. doi: 10.1007/s10681-018-2149-8

Blair, M. W., Astudillo, C., Grusak, M. A., Graham, R., \& Beebe, S. E. (2009). Inheritance of seed iron and zinc concentrations in common bean (Phaseolus vulgaris L.). Molecular Breeding, 23(2), 197-207. doi: $10.1007 / \mathrm{s} 11032-008-9225-z$

Blair, M. W., González, L. F., Kimani, P. M., \& Butare, L. (2010b). Genetic diversity, intergene pool introgression and nutritional quality of common beans (Phaseolus vulgaris L.) from Central Africa. Theoretical and Applied Genetics, 121(2), 237-248. doi: 10.1007/s00122-010-1305-x

Blair, M. W., Medina, J. I., Astudillo, C., Rengifo, J., Beebe, S. E., Machado, G., \& Graham, R. (2010a). QTL for seed iron and zinc concentration and content in a Mesoamerican common bean (Phaseolus vulgaris L.) population. Theoretical and Applied Genetics, 121(6), 1059-1070. doi: $10.1007 / \mathrm{s} 00122-010-1371-0$

Broughton, W. J., Hernandez, G., Blair, M., Beebe, S., Gepts, P., \& Venderleyden, J. (2003). Bean (Phaseolus spp) - model food legumes. Plant and Soil, 252(1), 55-128. doi: 10.1023/A:1024146710611 
Camaschella, C. (2015). Iron-deficiency anemia. The New England Journal of Medicine, 372(19), 1832-1843. doi: 10.1056/ NEJMra1401038

Carbonell, S. A. M., Chiorato, A. F., Gonçalves, J. G. R., Perina, E. F., \& Carvalho, C. R. L. (2010). Tamanho de grão comercial em cultivares de feijoeiro. Ciência Rural, 40(10), 2067-2073. doi: 10.1590/ S010384782010005000159

Cichy, K. A., Caldas, G. V., Snapp, S. S., \& Blair, M. W. (2009). QTL analysis of seed iron, zinc, and phosphorus levels in an Andean bean population. Crop Science, 49(5), 17421750. doi: $10.2135 /$ cropsci 2008.10 .0605

Cruz, C. D. (2016). Genes software - extended and integrated with the R, Matlab and Selegen. Acta Scientiarum Agronony, 38(4), 547-552. doi: 10.4025/actasciagron. v38i4.32629

Comissão Técnica Sul Brasileira de Feijão (2012). Informações técnicas para o cultivo de feijão na Região Sul brasileira 2012. Florianópolis: Epagri.

Erfatpour, M., Navabi, A., \& Pauls, K. P. (2018). Mapping the non-darkening trait from 'Witrood boontje' in bean (Phaseolus vulgaris). Theoretical and Applied Genetics, 131(6), 1331-1343. doi: 10.1007/s001 22-0183081-y

Jost, E., Ribeiro, N. D., Maziero, S. M., Possobom, M. T. D. F., Rosa, D. P., \& Domingues, L. S. (2013). Comparison among direct, indirect and index selections on agronomic traits and nutritional quality traits in common bean. Journal of the Science Food and Agriculture, 93(5), 1097-1104. doi: 10.1002/jsfa. 5856
Katuuramu, D. N., Hart, J. P., Porch, T. G., Grusak, M. A., Glahn, R. P., \& Cichy, K. A. (2018). Genome-wide association analysis of nutritional composition-related traits and iron bioavailability in cooked dry beans (Phaseolus vulgaris L.). Molecular Breeding, 38(44), 1-18. doi: 10.1007/ s11032-018-0798-x

Lemos, L. B., Mingotte, F. L. C., \& Farinelli, R. (2015). Cultivares. In O. Arf, L. B. Lemos, R. P. Soratto, \& S. Ferrari (Eds.), Aspectos gerais da cultura do feijão (Phaseolus vulgaris L.) (pp. 181-207). Botucatu: FEPAF.

Martins, S. M., Melo, P. G. S., Faria, L. C., Souza, T. L. P. O., Melo, L. C., \& Pereira, H. S. (2016). Genetic parameters and breeding strategies for high levels of iron and zinc in Phaseolus vulgaris L. Genetics and Molecular Research, 15(2), 1-11. doi: 10.4238/gmr.15028011

Maziero, S. M., Ribeiro, N. D., \& Facco, H. S. (2016). Genetic parameters of agronomic and nutritional traits of common bean (Phaseolus vulgaris L.) population with biofortified grains. Australian Journal of Crop Science, 10(6), 824-830. doi: 10.21475/ajcs.2016.10.06.p7373

Maziero, S. M., Ribeiro, N. D., \& Storck, L. (2015). Simultaneous selection in beans for architecture, grain yield and minerals concentration. Euphytica, 205(2), 369380. doi: 10.1007/s10681-015-1392-5

Miyazawa, M., Pavan, M. A., Muraoka, T., Carmo, C. A. F. S. do, \& Melo, W. J. (2009). Análise química de tecido vegetal. In F. C. Silva (Ed.), Manual de análises químicas de solos, plantas e fertilizantes (pp. 191223). Brasília: EMBRAPA Informação Tecnológica. 
Mukamuhirwa, F., Tusiime, G., \& Mukankusi, M. C. (2015). Inheritance of high iron and zinc concentration in selected bean varieties. Euphytica, 205(2), 349-360. doi: 10.1007/ s10681-015-1385-4

Parmar, N., Singh, N., Kaur, A., \& Thakur, S. (2017). Comparison of color, antinutritional factors, minerals, phenolic profile and protein digestibility between hard-to-cook and easy-to-cook grains from different kidney bean (Phaseolus vulgaris) acessions. Journal of Food Science and Technology, 54(4), 10231034. doi: 10.1007/s13197-017-2538-3

Possobom, M. T. D. F., Ribeiro, N. D., Zemolin, A. E. M., \& Arns, F. D. (2015). Genetic control of the seed colour of Middle American and Andean bean seeds. Genetica, 143(1), 4554. doi: 10.1007/s10709-014-9811-4

Prasad, A. S. (2014). Impact of the discovery of human zinc deficiency on health. Journal of Trace Elements in Medicine and Biology, 28(4), 357-363. doi: 10.1016/j. jtemb.2014.09.002

Ramalho, M. A. P., Ferreira, D. F., \& Oliveira, A. C. de. (2000). Experimentação em genética e melhoramento de plantas. Lavras: Universidade Federal de Lavras.

Resende, M. D. V. de, \& Duarte, J. B. (2007). Precisão e controle de qualidade em experimentos de avaliação de cultivares. Pesquisa Agropecuária Tropical, 37(3), 182-194.

Ribeiro, E. H., Pereira, M. G., Coelho, K. de S., \& Freitas, S. de P. F., Jr. (2009). Estimativas de parâmetros genéticos e seleção de linhagens endogâmicas recombinantes de feijoeiro comum (Phaseolus vulgaris L.). Revista Ceres, 56(5), 580-590.
Ribeiro, N. D., Domingues, L. da S., Gruhn, E. M., Zemolin, A. E. M., \& Rodrigues, J. de A. (2014a). Desempenho agronômico e qualidade de cozimento de linhagens de feijão de grãos especiais. Revista Ciência Agronômica, 45(1), 92-100. doi: 10.1590/ S1806-66902014000100012

Ribeiro, N. D., Domingues, L. da S., Zemolin, A. E. M., \& Possobom, M. T. D. F. (2013). Selection of common bean lines with high agronomic performance and high calcium and iron concentrations. Pesquisa Agropecuária Brasileira, 48(10), 1368-1375. doi: 10.1590/S0100-204X2013001000008

Ribeiro, N. D., Mezzomo, H. C., \& Santos, G. G. dos. (2019a). Genetic parameters and combined selection for seed coat color and macrominerals in Mesoamerican common bean lines. Genetics and Molecular Research, 18(2), 1-14. doi: 10.4238/gmr18224

Ribeiro, N. D., Possebom, S. B., \& Storck, L. (2003). Progresso genético em caracteres agronômicos no melhoramento do feijoeiro. Ciência Rural, 33(4), 629-633. doi: 10.1590/S0103-84782003000400006

Ribeiro, N. D., Rodrigues, J. de A., Prigol, M., Nogueira, C. W., Storck, L., \& Gruhn, E. M. (2014b). Evaluation of special grains bean lines for grain yield, cooking time and mineral concentration. Crop Breeding and Applied Biotechnology, 14(1), 15-22. doi: 10.1590/S1984-70332014000100003

Ribeiro, N. D., Steckling, S. de M., Maziero, S. M., Silva, M. J. da, Kläsener, G. R., \& Casagrande, C. R. (2017). Experimental precision of grain yield components and selection of superior common bean lines. Euphytica, 213, 1-11. doi: 10.1007/ s10681-017-2078-y 
Ribeiro, N. D., Steckling, S. de M., Mezzomo, H. C., \& Somavilla, I. P. (2019b). Genetic parameters and combined selection for phosphorus, phytate, iron, and zinc in Mesoamerican common bean lines. Ciência e Agrotecnologia, 43, 1-13. doi: 10.1590/1413-7054201943027818

Ribeiro, N. D., Storck, L., \& Poersch, N. L. (2008). Classificação de lotes comerciais de feijão por meio da claridade do tegumento dos grãos. Ciência Rural, 38(7), 20422045. doi: 10.1590/S0103-84782008000 700039

Soares, M. S., Jr., Caliari, M., Bassinello, P. Z., Fernandes, P. M., \& Becker, F. S. (2012). Características físicas, químicas e sensoriais de feijões crioulos orgânicos, cultivados na região de GoiâniaGO. Revista Verde de Agroecologia e Desenvolvimento Sustentável, 7(3), 109118.

Soltani, A., Bello, M., Mndolwa, E., Schroder, S., Moghaddam, S. M., Miklas, P. N.,... Mcclean, P. (2016). Targeted analysis of dry bean growth habit: interrelations among architectural, phenological, and yield components. Crop Science, 56(6), 30053015. doi: 10.2135/cropsci2016.02.0119
Suárez-Martínez, S. E., Ferriz-Martínez, R. A., Campos-Vega, R., Elton-Puente, J. E., Carbot, K. de la T., \& García-Gasca, T. (2016) Bean seeds: leading nutraceutical source for human health. CyTAJournal of Food, 14(1), 131-137. doi: 10.1080/19476337.2015.1063548

Subandi, W., Compton, A., \& Empig, L. T. (1973). Comparison of the efficiencies of selection indices for three traits in two variety crosses of corn. Crop Science, 13(2), 184-186. doi: 10.2135/cropsci1973.001 $1183 \times 001300020011 x$

Tryphone, G. M., \& Nchimbi-Msolla, S. (2010). Diversity of common bean (Phaseolus vulgaris L.) genotypes in iron and zinc contents under screenhouse conditions. African Journal of Agricultural Research, 5(8), 738-747. doi: 10.5897/AJAR10.304

Vencovsky, R., \& Barriga, P. (1992). Genética biométrica no fitomelhoramento. Ribeirão Preto: Revista Brasileira de Genética.

Zemolin, A. E. M., Ribeiro, N. D., Casagrande, C. R., Silva, M. J. da, \& Arns, F. D. (2016). Genetic parameters of iron and zinc concentrations in Andean common bean seeds. Acta Scientiarum Agronomy, 38(4), 439-446. doi: 10.4025/actasciagron.v38 i4.30652 